Richard R. John*

\title{
3 When Techno-Diplomacy Failed: Walter S. Rogers, the Universal Electrical Communications Union, and the Limitations of the International Telegraph Union as a Global Actor in the 1920s
}

The Great War of 1914-1918 transformed the relationship of the United States to Europe, creating a raft of new opportunities for commerce, diplomacy, and public understanding. Among the public figures to find these possibilities inspiring was Walter S. Rogers, a liberal journalist dedicated to the cause of improving the quality of foreign reporting. Rogers was best known to the public in 1918 as the director of a New York City-based international news service that he operated for the Committee on Public Information, the government's official news agency. Rogers fervently believed that the foreign press was systematically distorting US news by foregrounding sensationalistic atrocity stories and underreporting uplifting accounts of current events. To set the record straight, Rogers oversaw an ambitious government project to feed foreign journalists carefully curated news reports that they could then run in their own publications. ${ }^{1}$

Rogers's wartime experience led him to promote a journalism-centric liberal internationalism. Liberal internationalism was not new in 1918. Yet it received a boost from US President Woodrow's Wilson eloquent paeans to freedom and democracy, as well as the high hopes with which many invested the diplomatic ne-

\footnotetext{
* Columbia University, USA

1 Walter S. Rogers, "Tinted and Tainted News," Saturday Evening Post, 21 July 1917, 17; Walter S. Rogers, Testimony, 10 October 1919, International Conference to Consider Questions Relating to International Communications: Hearings before the Committee on Foreign Affairs, $66^{\text {th }}$ Cong., $1^{\text {st }}$ sess. (Washington, DC: Government Printing Office, 1919): 3-8; Creel, How We Advertised America, $250-260$. Special thanks to Andreas Fickers, Tony Rutkowski, and James Schwoch for their expert critique of an earlier draft of this essay. For suggestions and advice, I am also grateful to Gene Allen, Gabriele Balbi, John M. Hamilton, Daniel R. Headrick, Heather Heywood, Simone Müller, Bailey Pierson, Michael Stamm, Heidi Tworek, Jonathan R. Winkler, Dwayne R. Winseck, Emilie Yu Marine Xie, Qiguang Yang, and the participants in the 2017 conference on the history of the International Telecommunication Union at the University of Luxembourg. All errors of fact and interpretation are my own.
} 
gotiations in Paris that followed the cessation of hostilities in western Europe in November 1918. ${ }^{2}$ In Rogers's view, liberal internationalism presupposed the es tablishment of an international organization dedicated to providing journalists with cheap and abundant information on current events. Toward this end, Rog. ers hoped to combine in a single organization the regulation of the world's cable and radio networks, two networks that had previously been regulated under separate international conventions. This new organization, in turn, would supersede the International Telegraph Union, a membership-based federation of government-appointed technical experts, based in Berne, Switzerland, that had long coordinated the regulation of international communications.

In Roger's opinion, radio networks should not, like cable networks, be licensed to private corporations. ${ }^{3}$ On the contrary, he hoped that radio networks -which, at this time, were mostly point-to-point-would be administered directly by the governments of the nations in which they were based, and configured to support print-based news media. The news outlets that Rogers had in mind were primarily metropolitan newspapers, which Rogers assumed would remain the principal medium for the circulation of information on current events. For Rog. ers, liberal internationalism encouraged the emergence of a thriving, uncensored, metropolitan press untainted by propaganda, an institution that in his view had flourished in the United States, but none of the other Great Powers, during the Great War.

In the short run, Rogers's project flopped. His proposal for the unification of cable and radio regulation failed to overcome the objections of its critics, and radio broadcasting in the United States emerged as an advertising driven broadcast medium, an outcome Rogers deplored. In the long run, however, Rogers's commitment to expanding facilities for the circulation of information would find expression in the innovative frequency allocation protocols that emerged out of the 1927 Washington, DC-based International Radiotelegraph Conference. Prior to 1927, the allocation of frequencies in the electromagnetic spectrum had been based on political jurisdiction, a convention that empowered national governments to determine how their portion of the spectrum would be used. Follow-

2 Manela, The Wilsonian Moment.

3 Corporate ownership and operation of network providers is often termed "private," a convention I observe in this essay. While conventional, this designation can be confusing, since the managers of ostensibly private enterprises such as the Radio Corporation of America or the Bell System (that is, the holding company American Telephone \& Telegraph, its long lines and research division, and its associated operating companies) recognized that any corporation that facilitated the production and circulation of information was a "public utility" and, as such, properly subject to federal, state, and municipal law. 
ing the conference, wavelengths would be allocated by the service they provided, rather than the jurisdiction to which they had been assigned. Jurisdiction-specific, location-based allocations favored government network providers, such as the Postal, Telegraph, and Telephone ministries in Europe and Japan. Servicespecific, application-based allocations, in contrast, encouraged technically advanced network providers, which included, in the United States, corporations, to obtain exclusive access to specific wavelengths. Ironically, given Rogers's preference for government owned radio stations, the restructuring of the electromagnetic spectrum to favor service over location helped to entrench the very technocratic corporatism that Rogers opposed. ${ }^{4}$

Rogers justified his liberal internationalism in a rhetorically expansive, multi-page memorandum that he prepared at the request of US President Woodrow Wilson in February 1919, four months after the Armistice, and twenty-one months before the first regularly scheduled US-based radio broadcast. Rogers was based at this time in Paris, where he was coordinating news coverage of the US delegation to the Paris Peace Conference, a logical follow-up to the work he has performed in New York City during the war for the Committee on Public Information. "Barriers to the flow of news from nation to nation," Rogers declared in his preamble, should be "removed in the general public interest": "The ideal is a world-wide freedom for news, with important news going everywhere." Under existing conditions, Rogers concluded, the unimpeded global flow of information had become an indispensable prerequisite for world peace: "The steady extension of democratic forms of government and the increasing closeness of contact between all parts of the world point to the conclusion, that the ultimate basis of world peace is common knowledge and understanding between the masses of the world. Hence the distribution of intelligence in the form of news becomes of the utmost importance." ${ }^{5}$ To hasten the free flow of information across national borders, Rogers looked to the League of Nations, which, or so he hoped, would become a center for the exchange of technical information regarding radio that would work closely with whatever protocols technical experts might see fit to devise. ${ }^{6}$

Rogers's expansive conception of the possibilities of the press would inform the position that he took as a delegate to an international communications conference that the victorious powers convened in Washington, DC, in October 1920. Attendance at this conference was limited to five countries: the United Kingdom,

4 Schwoch, The American Radio Industries, chapter 3.

5 Rogers, "Memorandum on Wire and Radio Communications," 429, 441.

6 Ibid., 441. 
France, the United States, Italy, and Japan. Its original rationale was to resolve number of issues left over from the Paris Peace Conference. Of these the most pressing was the legal status of German cables that the allies had cut, and in some instances, repurposed, during the war. Yet the conference soon acquired the much more open-ended rationale of drafting the charter for an entirely new international organization-a Universal Electrical Communications Union -that would create for the first time in world history a single forum for the reg. ulation of every form of electrically mediated communications-telegraphy, tel. ephony, cable, and radio. No longer would cable and radio be regulated under different international conventions, as they had been in the past. ${ }^{7}$

The failure of the 1920 Washington conference reveals some of the limita. tions of liberal internationalism. These constraints become especially evident if one views the conference through Rogers's eyes, which it is possible to do, given the existence in the National Archives of several boxes of Rogers's official files. ${ }^{8}$ Little used by historians, these papers provide a window on the challenges

7 “Comité radiotélégraphique international," Jourmal Télégraphique, September 1921, 178; “Aprés la conference de Londres," Journal Télégraphique, July 25, 1922, 124.

8 Rogers is a neglected figure. Though he sometimes gets a walk-on role in historical accounts of US communications during the war years and its immediate aftermath, the specific nature of his contribution is typical overlooked. For one exception, see Winseck and Pike, Communications and Empire, 13, 262-74. Winseck and Pike credit Rogers with inventing in the 1910s more-0rless out of whole cloth the "free flow of information doctrine" that would become "bedrock prin. ciples of US international communications policy after the Second World War" (13). This claim overstates the novelty of Roger's faith in the democratic potential of information, which was shared by generations of journalists, public figures, and educators, and can be traced back at least as far as the Enlightenment. In addition, it obscures the kind of information that Rogers hoped would circulate freely. Rogers had no interest in facilitating the flow of information tout court; rather, he hoped to improve the facilities for information-gathering and information-dissemination for newspaper journalists specializing in world affairs. Winseck and Pike based their argument in part on the remarkable paean to Rogers that was penned in 1943 by Co. lumbia Journalism School dean, Carl W. Ackerman, in his annual dean's report. In this report, Ackerman hailed Rogers as the "leading authority in the United States today on international communications in relation to the flow of news" and the "originator of the idea of international press freedom both ideologically and practically." To drive this point home, Ackerman reprinted as "source documents" copious extracts from Rogers's postwar writings on international communications, including Rogers's 1919 memorandum to Wilson, which Ackerman erroneously claimed to have never before been published. Ackerman's admiration for Rogers was informed by Ackerman's personal experience as a journalist who had worked closely with the US government during the First World War, a circumstance that highlights an often overlooked continuity in twentieth-century US information policy: Long before the Cold War, government officials and journalists had collaborated to broadcast flattering news about the United States to the world. Report of the Dean of the Graduate School of Journalism for the Academic Year Ending June 30, 
that confronted US public figures like Rogers who had hoped in the aftermath of the Great War to expand the role of the United States in world affairs. 9

\subsection{The Rationale for a Universal Electrical Communications Union}

The decision to hold the 1920 conference in Washington, DC, posed for its organizers a number of challenges. Among them was the fact that the US government was not a signatory to the International Telegraph Convention, and therefore not a member of the International Telegraph Union. This was true, even though US network providers had participated in various Telegraph Union-sponsored meetings for many decades. In the case of radio, the situation was quite different. The discovery around 1900 that radio could facilitate ship-to-shore communications prompted the US government to send delegates to the Preliminary Conference on wireless telegraphy in Berlin in 1903. Though the US Congress would not ratify an international radiotelegraph convention until 1912, the US Navy had monitored international radio regulation since 1903 and would keep close watch on the deliberations in Washington in $1920 .^{10}$

Rogers was well aware of the anomalous position of the United States in the realm of international communications, and worked diligently to make the proposed new organization palatable to the principal US stakeholders, and, in particular, to government officials, journalists, and merchants engaged in international trade.

By far the most prominent government official in Rogers's camp was President Wilson. Rogers had earned high praise from Wilson administration insiders for the wartime news bureau that Rogers had operated for the Committee on Public Information, leading Wilson to hail him as the "best posted man we have" on the complicated questions arising out of the disposition of the German cables seized by the allies during the war. ${ }^{11}$

Rogers shared Wilson's visceral dislike of big business and was broadly sympathetic to the determination of Wilson's postmaster general Albert S. Burleson

1943 (New York: Columbia University Press, 1943): 8; Menard McCune and Hamilton, “My object is to be of service to you."

9 Rogers's files can be found in RG 43, National Archives, Suitland, Maryland (hereafter NA). 10 Douglas, Inventing American Broadcasting, chapter 3.

11 Woodrow Wilson interview, 27 September 1920, in Papers of Woodrow Wilson, edited by Arthur S. Link (Princeton: Princeton University Press, 1966-1994), vol. 66, 154; Aitken, The Continuous Wave, 262-79. 
to lower international cable rates and retain radio under tight government con. trol. All three men were democratic statists skeptical of corporate control of com. munications networks and sympathetic to their regulation and even outright ownership by the government. Rogers could rhapsodize about the "illimitable possibilities" of this new medium: there was no "technical reason," he mused, why at some point in not-too-distant future a radio message could not be inter. cepted in "every house in the world." 12 Yet the future of the new medium re. mained in 1919 an open question, and filled Rogers and his fellow democratic statists with foreboding.

The radio network that Rogers envisioned in 1919 remained a point-to-point medium, rather than the broadcast medium it would soon become. This fundamental assumption, which was rooted in Rogers's background in and commit ment to journalism-and in particular to the voracious demand of newspaper publishers for cheap, timely, and abundant information-shaped not only his ap. proach to the Washington conference but also his later career as a director of the Institute of Current World Affairs, a philanthropic organization based first in New York City, and today in Washington, DC, that since the 1920s has provided journalists with fellowships to broaden their horizons by traveling abroad. ${ }^{13}$

Rogers's proposals regarding international communications built on his con. viction that both cable and radio should be configured to facilitate the work of newspaper publishers. Advantageous rates for the transmission of time-sensitive news dispatches were key and Rogers presumed that these could only be assured if an international organization, such as the proposed Universal Electrical Communications Union, had the authority to fix cable and radio rates and mandate preferential access for journalists' time-sensitive dispatches. Each nation, in Rogers' view, should "nationalize" its radio facilities, since private enterprise would never expand rapidly enough to meet the anticipated demand. A "laissez-faire policy," Rogers predicted, might well lead to "slow progress, confusion, and a monopolistic control, with self-interest rather than the general good of humanity furnishing the directive motive." ${ }^{14}$

To realize the potential of the new medium would exceed the capabilities of even the largest and most ambitious of the world's corporations: "The working out of such a comprehensive system of radio communication, the making of schedules, the standardization of practice, and so forth, goes beyond the possibilities of private enterprise or of the interest of any one nation." ${ }^{15}$ Should the

12 Rogers, "Memorandum," 430 - 31.

13 "Walter S. Rogers," Washington Post, November 1,1965; Hapgood, Charles R. Crane, 91-92 14 Rogers, "Memorandum," 431.

15 Ibid., 431-32. 
world's statesmen permit this situation to persist, global commerce would be stifled, the press would remain unnecessarily "provincial," and the "propagandist" would thrive: "If statesmanship has the vision and the organizing ability, the most widely separated communities can be made neighbors, trading with each other, interested in each other, understanding each other, learning from each other." 16

The regulation of the world's cable network presented a different kind of challenge. Like most informed observers, Rogers took it for granted that this network, which for many years had been operated by a tight cartel of multinational corporations, had been and would remain closely allied with the British government, a circumstance that he viewed with alarm. Rogers did not, however, recommend that cable corporations be "internationalized" and put under the jurisdiction of the League of Nations, a suggestion, he conceded, that "had been made." ${ }^{17}$ Rather, he hoped they might be run like other "public utilities"-such as, for example, telephone exchanges, gas works, and electric power stations that, or so he assumed, had traded low volume and high rates for high volume and low rates. In such a world, Rogers mused, cable rates would be set so low that, in the lucrative North Atlantic market, letter-writing would become obsolete. ${ }^{18}$

The primary exception was the Pacific, where Rogers knew on the basis of personal experience that the nation-based public utility model could never succeed. Here, and only here, he proposed the internationalization of the cable network by encouraging intergovernmental cooperation between the United Kingdom, the United States, Japan, and China to provide "ample facilities at low rates." ${ }^{19}$

To allay popular suspicion toward the new international organization, Rogers downplayed its novelty. The United States had long played a prominent role in international organizations to facilitate the circulation of information, Rogers reminded lawmakers in October 1919. A case in point was the Universal Postal

16 Ibid., 442. Rogers's journalistic boosterism won the admiration of public figures across party lines. For example, though Wilson's successor, Warren G. Harding was a Republican rather than a Democrat, Harding had been a small-town newspaper editor-which prompted him quite understandably to hail approvingly the low cable tolls that Rogers predicted his proposed Universal Electrical Communications Union would bring. "A Universal Communications Union," Washington Herald, November 19, 1920; "Harding Discusses Cable Tolls with Washington Correspondents," Editor and Publisher 53 (December 11, 1920).

17 Rogers, "Memorandum," 433.

18 Ibid., 434-35.

19 Ibid., 440. 
Union, to which the United States had belonged since its founding in 1874, and for which US postmaster general Montgomery Blair had helped lay the ground. work in the 1860 s during the administration of Abraham Lincoln. ${ }^{20}$

The decision to incorporate the familiar words "Universal" and "Union" into the name of the new organization originated in Washington, DC. Neither of these two words can be found in the early printed draft of the convention in Rogers's files in which the new organization is referred to merely as a "Combined Telegraph and Radio Convention." ${ }^{21}$ By the time the Washington conference finished its deliberations, however, it had been officially branded the Universal Electrical Communications Union-a conciliatory gesture, very possibly of Rogers's own devising, that linked it with an organization in which the United States had long belonged.

The authorship of this early draft of the convention remains something of a mystery. In all probability, given its high level of technical detail, it had been prepared by an administrator in the British Post Office, presumably under the supervision of W. J. Brown, the British civil servant mostly closely linked with the 1920 conference. ${ }^{22}$ If Brown or someone in his office had indeed taken the lead in preparing this draft, it should come as no surprise that the word "universal" was nowhere to be found, since, in this period, British civil servants tended to asso. ciate "universal" with the British Empire, rather than the world. ${ }^{23}$

When lawmakers asked Rogers who had originally proposed that the conference be held in Washington, he replied he did not know. ${ }^{24}$ Almost certainly this was a feint..$^{25}$ Had Rogers acknowledged that the project had substantial British

20 Rogers, Testimony, October 10, 1919, International Conference, 12. The original idea for the convening of a conference to give a "general direction of the whole communication field," Rog. ers added, "was based on the International Postal Union" (12).

21 "Draft of Combined Radio and Telegraph Convention," Correspondence of the Secretariat, dossier 300-341, RG 43, NA.

22 "Digest of Minutes of First Plenary Meeting Preliminary Session of the International Conference on Electrical Communications," October 8, 1920, RG 43, NA; Schwoch, American Radio Industries, 64-65.

23 John, "The Public Image of the Universal Postal Union in the Anglophone World."

24 Rogers, Testimony, International Conference, 12, 17.

25 The British provenance of the proposed amalgamation of the cable and radio conventions was an article of faith at the Radio Corporation of America, the largest US manufacturer of radio equipment. To drive this point home, a Radio Corporation of America publicist published a pamphlet in May 1921 that branded the proposed Universal Electrical Communication Union a British trick to perpetuate British hegemony in global communications by protecting the interests of British cable network providers: "The proposal to amalgamate the radio convention with the old wire convention based upon European practice came, as we understand, from the British. They are the only ones who have expressed formal approval of that principle. It is 
support, this might well have sealed its fate, given the widespread popular distrust of the influence that the British government had long exerted in the international cable business, and the looming fear that the British-based Marconi Company might dominate the still nascent radio business.

The postal-electrical analogy intrigued not only Rogers, but also President Wilson. In December 1919, for example, Wilson informed the secretary of state -in a letter drafted by Wilson's wife Edith Galt Wilson, who was filling in for the ailing president, who had been felled by a stroke-that the Post Office Department, and not the State Department, should head up the US delegation to the communications conference. ${ }^{26}$ It is, thus, perhaps not surprising that, at the top of the first page of the draft convention in Roger's files, someone penciled in the phrase "Universal Communications Union," or that the margins of the draft include several inserts, both handwritten and typed, comparing the regulations of the new organization with those adopted by the Universal Postal Union. ${ }^{27}$

If the allusions to the Universal Postal Union reassured critics, any reference to the League of Nations raised red flags. This was especially true following the rejection by the US Senate of US membership in League in November 1919. It is

obviously to their interest: they control cable communications throughout the world and naturally desire to bring radio under the same control" (italics in original). Why, the company publicist elaborated, had the organizers of the 1920 Washington conference ignored the US-government-approved EU-F-GB-I protocol of 25 August 1919? To pose the question was to answer it. The EU-F-GB-I protocol was a narrowly technical document, drafted in consultation with the corporation-friendly US Commerce Department, that had sidestepped the sensitive diplomatic issue of corporate control, making it unsuitable for the techno-diplomatic coup that Rogers and his British colleagues had tried to orchestrate: "The EU-F-GB-I Commission, as well as the Department of Commerce Committee, attempted to deal with only the technical aspects of the situation and not with diplomatic questions nor with those involving general policies." The exclusion of corporate delegates from the 1920 Washington conference established a pattern-much resented by US corporate leaders-that carried over to the post-Commodore Hotel June-August 1921 Paris meeting of the technical committee on international radiocommunication. Despite the protestations of US corporate leaders, the US delegation to this meeting, which had been convened explicitly to refine the regulations devised in the 1920 Washington conference, did not include a single corporate representative. Memorandum of Radio Corporation of America with Reference to the Proposed Universal Communications Union (n. p. 1921), 14, 18, box 3, dossier 5-30, entry 66, RG 43, NA; Comité Technique de Radiocommunications Internationales (Paris: Imprimerie Nationale, 1921): 47, ITU Library \& Archives, Switzerland; Tomlinson, The International Control of Radiotelecommunications, 49.

26 Edith Bolling Galt Wilson to Robert Lansing, December 24, 1919, in Papers of Woodrow Wilson, vol. 64, 228.

27 "Draft of Combined Radio and Telegraph Convention," RG 43, NA. 
thus not surprising that, though the early draft of the proposed convention Rogers's files presumed that the organization would come under the jurisdictio of the League, in the final draft, all references to the League had been droppe The new organization was, instead, to be a freestanding council under the jur diction of representatives from the United States, France, the United Kingdon Italy, and Japan, and "four other representatives, chosen by the other signato? parties, to be selected at each General Conference of High Contracting Parties."

The prospect that the United States might join an international communica tions organization had a solid base of support among US merchants engaged foreign trade. Though the Washington conference was closed to the press, and it proceedings secret, it attracted the attention of several of the country's most in fluential business groups, who signed a joint statement endorsing its objective: shortly before it convened. The venue at which the signatories met was revealing It took place not in Washington, DC, which remained a commercial backwater, but in New York City at India House, a men's club for merchants interested in international commerce. Among the signatories were the US Chamber of Com. merce, the New York Chamber of Commerce, the Merchants Association of New York, the American Bankers Association, the American Manufacturers Ex port Association, and the National Association of Manufacturers. In their joint statement, the signatories expressed their support for the establishment an " $\mathrm{n}$. ternational Telegraphic Communications Union"-modeled, they took care to specify, on the Universal Postal Union-that would facilitate the standardization of cable rates, ensure "free and unrestricted competition" among network providers, and guarantee that every radio broadcast station was owned by a US citizen. $^{29}$

The journalists' wish list was even more specific. In an October 1920 meeting of the American Newspaper Publishers Association that was convened at the headquarters of the New York World in response to a request by Postmaster Gen. eral Burleson and Undersecretary of State Norman Davies, the publishers lob. bied for low and uniform rates for the transmission of news dispatches by cable and wireless, preferential high-speed access to both the cable and wireless networks, the abolition of monopoly grants for cable providers, the continuation of wireless transmission by the navy, and the establishment of an informational

28 Universal Electrical Communications Union: Revised Draft of Convention and Regulations in p., 1922), article $17,3$.

29 "Recommendations of the India House Conference," entry 72, RG 43, NA. 
clearinghouse in a major city on every continent to keep journalists abreast of the relevant technical issues. ${ }^{30}$

\subsection{Corporate Opposition to the Universal Electrical Communications Union}

The enthusiasm of journalists, government officials, and merchants active in foreign trade for the establishment of a new international organization to regulate cable and radio would be challenged, and in the end overbalanced, by the hostility toward the new organization of the managers of telegraph, telephone, cable, and radio corporations. To understand why these network providers found this new organization so threatening, it is useful to know something about international communications regulation in the decades preceding the Washington conference.

The regulation of international communications in the 1920 s was predicated on the venerable premise that communications networks that crossed political boundaries were best coordinated by international organizations whose voting members represented the territorially bounded jurisdictions that these networks linked. Corporations such as US telegraph giant Western Union could and did send delegates to international conferences, yet these delegates did not have voting rights and were not formal members of the International Telegraph Union, an anomaly that corporate leaders repeatedly invoked in defending their opposition to any new international organization that would perpetuate their marginalization. Spatially based norms shaped the deliberations of the International Telegraph Union, the Universal Postal Union, and the International Radiotelegraph Union. Each of these organizations derived their authority from a formal, treaty-like agreement that had been endorsed by representatives of the territorially bounded jurisdictions that had called them into being. It was in part for this reason that these organizations were all called "unions."

The International Telegraph Union and the International Radiotelegraph Union regulated international communications through conventions that their members had ratified. These conventions were by 1920 quite elaborate, and included a raft of arcane protocols devised by technical experts. The resulting protocols were inter-national, in the sense that they had been designed to accommodate the interests of member nations. One such team had drafted the first version

30 "Memorandum of Cable-Using Newspapers and Press Associations of America," entry 75, box 3, RG 43, NA. 
of the proposed convention that Rogers and his colleagues debated in Washing ton in the Fall of 1920. The art of crafting such protocols can be called "techno. diplomacy."

The hostility of US network providers toward the proposed new organization was catalyzed by their discovery that a small group of US government experts. who, of course, included Rogers-had been cooperating with their British coun. terparts to establish a new international organization to regulate every electicical communications medium: telegraphy, telephony, cable, and radio. The assertion that the proposed organization had been modeled on the Universal Postal Union -a circumstance that Rogers had hoped would make it seem less exotic-wasfor corporate network providers no comfort at all. This was because the Postal Union worked exclusively with governments-prompting corporate leaders, not altogether implausibly, to demonize the new organization as the first step in a secret campaign to nationalize the entire electrical communications sector.

The realization that the new organization's backers included Albert S. Burle. son did little to allay these concerns. Burleson, after all, was an outspoken democratic statist who, as postmaster general, had vocally backed a government takeover of telegraphy, telephony, and cable, and who, under the cover of mili. tary exigency, would briefly operate all three networks under government control. Should the United States join the new international organization, or so warned the presidents of Western Union and Commercial Cable on the eve of the 1920 Washington conference, this would inevitably increase the likelihood that their corporations might find themselves subject to onerous regulations intended to further the interests of their government-owned and government-oper. ated rivals. ${ }^{31}$

The hostility of corporate network providers toward the new organization boiled over in an extraordinarily contentious two-day private meeting between Rogers and several of the country's most important communications executives that took place at the Commodore Hotel in New York City in May 1921. The frank and often heated discussions that took place during this meeting, which, forthnately for the historian, were professionally transcribed, threw into sharp relief the ideological gulf that separated Rogers's anti-corporate democratic statism -a holdover from the now-out-of-power Wilson administration-from the in creasingly self-confident technocratic corporatism of the country's business elite. American Telephone \& Telegraph executive John J. Carty complained bitterly about the exclusion of corporate-based technical experts from the 1920 Wash. ington meeting, while RCA counsel Charles Naeve reminded his colleagues that

31 "US May Partner in Wire Agreement," Washington, DC, Evening Star, September 29, 1920. 
Rogers favored the nationalization of radio broadcasting, an outcome that had had considerable support in the Wilson administration, but that corporate leaders vehemently opposed. The proposed treaty, Naeve protested, was "patterned entirely after the League of Nations, which subordinates national interests to the views of internationalism, which do not seem to be very popular." Will the US government support "any treaty which is based on Government ownership, as this seems to be"? ${ }^{32}$ Neither Carty nor Naeve regarded the techno-diplomacy of the Washington conference to be neutral and benign: if ostensibly apolitical experts were to define the rules of the game, they wanted their experts to be in the room.

Historians today who anachronistically read the history of the interwar period backward from the post-1989 neoliberal order, rather than forward from the Great Power rivalries of the fin de siècle, sometimes discount the importance of geopolitics in the public debates over global communications during the 1920s. US corporate leaders knew better. No one who attended the Commodore Hotel meeting-or who carefully reads the transcript of the discussions that occurred-could possibly overlook the central role that contemporaries ascribed to the struggle for control in global communications between the United Kingdom and the United States, or, for that matter, glibly assume that cable, wireless, or corporations lacked a national identity.

Corporate ownership of electrical network providers did not, it should be underscored, preclude all forms of government intervention. A case in point was the thorny question of government ownership. The managers of every US telegraph and cable corporation well understood that Congress had the right to purchase their assets at a mutually agreed upon valuation. For telegraph network providers, this right could be traced back to their acceptance of the National Telegraph Act of 1866; for cable network providers, to the various landing rights agreements into which they had entered..$^{33}$ The crux of the issue, that is, was not some absolute right to private property. Even so, network providers remained apprehensive about the consequences for their bottom line should the US government join an international communications organization dominated by nations in which every form of electrical communication was either owned or operated by the government or had come under tight government control. The Commercial Cable Company, explained its president, Clarence H. Mackay in 1921-in looking

32 "Conference between the American Delegates to the International Conference on Electrical Communications and Various Representatives of American Telegraph, Cable, and Radio Companies..." Commodore Hotel, New York, 26 May 1921, 299-300, 301-302, entry 72, RG 43, NA; Schwoch, American Radio Industries, 66-69.

33 John, Network Nation, 116-23; Mackay, Intemational Cable Communication, 11. 
back on the Washington conference-had no objection to the US joining the In. ternational Telegraph Union if his corporation could be protected from "unrea. sonable regulations, present and future" that would "not only destroy the enter. prise of a competitive service but reduce the private companies to the conditions of government ownership." ${ }^{34}$

It was a time-honored American tradition, Mackay explained, in reiterating the principled antimonopolism that in the United States had long been a ubiquitous feature of public discourse, to "encourage unrestricted commercial enter. prise." In elaborating on this position, Mackay underscored that both the US gov. ernment and the American people would "best be served" by "relying on the continuance of competitive enterprise," as opposed to, say, compelling the Us cable corporations to comply with rules that had been devised more for the pur. pose of "protecting European government telegraph systems" than for strength. ening corporate network providers. ${ }^{35}$ Here was one instance, of the several that could be cited, in which the time-honored US bias in favor of private enterprise, as opposed, that is, to government ownership, encouraged not only the regula. tory uncoupling of international communications networks from national governments, but also the operational separation of telegraphy, cable, and radio into different organizations, outcomes broadly congruent with the longstanding commitment of US lawmakers to antimonopoly as a civic ideal.

\subsection{The Legacy of the 1920 Washington Conference}

Writing in the first issue of Foreign Affairs in 1922, Rogers did his best to keep alive the rapidly receding idea that it would be beneficial for the country and the world if "electrical communications," by which he meant telegraphy, telephony, cable, and radio were operated on the "same basis" as the mail. Was it "fantastic idealism" to hope that every means of communications might be operated as a public service to promote the public good, as opposed to the status quo, in which, in the United States, electrical communications remained a corporate prerogative? Rogers thought not: "A postal service handling letters generally throughout the world for two or five cents is conceived on a radically different

34 Mackay, International Cable Communication, 19, 20.

35 Ibid., 20. 
basis from one which fixes its charges by distance and by what the traffic will bear and avoids unprofitable activities." ${ }^{36}$

Rogers's proposal prefigured the triumph of a government-dominated liberal internationalism in which public service supplanted private profit. This project would remain unrealized, Rogers recognized, so long as US participation in international communications conferences remained constrained by the narrow, short-term profit-oriented worldview of US corporations. If the United States were to participate in future communications conferences "solely to further the immediate interests of American cable and radio companies," Rogers brooded, he felt certain that its participation "would not be relished by those who envisage a worldwide network of communications operated on a public service basis." 37

Rogers's endorsement of a public service rationale for international communications fit well with, and had been largely shaped by, his journalistic experience. For Rogers, as for many of his fellow journalists, it was hard to distinguish the interests of the nation and the world from those of the press. Yet its appeal extended well beyond like-minded journalists, merchants, and government officials. In addition, it retained support among the many Americans who opposed private ownership of the electromagnetic spectrum, and helps explain why the 1927 US Radio Act unequivocally declared the airwaves public property, a position that would be endorsed later that year by the US delegation to the 1927 International Radiotelegraph Conference, which met in Washington, DC. ${ }^{38}$

The 1927 conference established the basic principles for the allocation of global electromagnetic spectrum that remains in force today. While this outcome was heralded by US radio broadcasters, it did nothing to allay their principled opposition to US membership in the International Telegraph Union. Not until 1932 would this situation change, when, in a concession to US corporations, the International Telegraph Union relaxed its membership rules to permit corporations a more active role in the formulation of technical standards. In the years to come, Rogers's anti-corporate liberal internationalism would recede in favor of a pro-corporate technocratic corporatism that was subtly concealed by the substitution in the organization's official name of "telegraph" for "telecommunication," a French neologism that had been coined by a French postal administrator several decades earlier to refer exclusively to communications networks exclusively under government control. ${ }^{39}$ Though the United States never joined

36 Walter S. Rogers, "International Electrical Communications," 144-45.

37 Rogers, "International Electrical Communications," 157.

38 Schwoch, "The American Radio Industry."

39 John, Network Nation, 12. 
the International Telegraph Union, it would become a founding member of the International Telecommunication Union, into which the Telegraph Union was folded in 1932.

The refusal of the United States to join the International Telegraph Union had few negative repercussions for US telegraph and cable network providers. In the case of radio, the situation was quite different. The successful commercialization in the 1900 s of one-to-one wireless telegraphy by the British-based Marconi Corporation confronted US lawmakers with a formidable challenge. In the absence of some kind of international agreement, it seemed entirely possible that the US navy would find it impossible to communicate by wireless with its warships at sea without relying on Marconi equipment. It should, thus, not come as a surprise that the US government took part in the 1903 and 1906 Berlin radiotelegraph conferences-the world's first-or, for that matter, that it sponsored the 1927 conference that restructured the allocation of the electromagnetic spectrum.

US insiders praised the 1927 conference for hastening, as Washington lawyer Harold S. LeRoy would later explain, the "more orderly regulation of rapidly growing world radio traffic." ${ }^{40}$ Private ownership of the electromagnetic spectrum was rejected out of hand, a concession not only to European delegates, but also to US supporters of a broad concept of public utility-including Rog. ers-who saw parallels between the regulation of the electromagnetic spectrum and the regulation of municipal franchise corporations. ${ }^{41}$

Support for government ownership of the electromagnetic spectrum extended even to RCA president James G. Harbord. Every system of "electrical communication" in the United States-Harbord conceded, in an article for Foreign Affairs that he published on the eve of the 1927 conference-was "of necessity a species of public utility." In keeping with this premise, Harbord underscored that the "ether" above US territorial limits was the property of the US people and could "only be used by license of the Secretary of Commerce." The ownership of radio broadcast stations, however, should, at least in the United States, remain private. This was because, Harbord elaborated, under US law the US gov-

40 Le Roy, "International Radiotelegraph Conference," 86-87.

41 The relationship between municipal franchise legislation and public utility regulation is a neglected topic in US communications history. In large part, this is because of the reluctance of communications historians to recognize the continuing role in the 1920 s of subnational juris. dictions in the formulation of radio regulations. Many of these regulations were shaped by the courts, which repeatedly found themselves adjudicating contests between rival radio broadcasters over the increasingly congested airwaves of the nation's largest large cities-including, in particular, New York and Chicago. 
ernment could not interfere with the "managerial or operations functions" of an "electrical communications company" so long as this corporation conducted its affairs in accordance with the "rule of law." ${ }^{42}$

Harbord's conclusion furnished a stark reminder of the anomalous position of US network providers in international communications. Most of the world's countries, Le Roy reflected, in summarizing the results of the 1927 conference, operated their communications networks as "Government monopolies." The US government, in contrast, did not. On the contrary, it made a critical distinction between "government regulations"-with which US telegraph, telephone, cable, and radio corporations had no quarrel-and "management regulations," which they emphatically opposed-since the latter were "in conflict with the traditional policy of the United States for private operation of communications." The "strong position" of the US delegation on the "broad question of policy" with regard to government ownership, Le Roy elaborated, had two salutary effects. First, it "dampened the ardor" of European government administrators for the "intensive and stifling" regulation of the new medium; and, second, it aroused in certain countries a "lively appreciation of the advantages of freedom from bureaucratic interference in the conduct of business activities which could be more efficiently handled under private control."${ }^{43}$

The 1927 Washington conference would long occupy a special place in the imagination of US communications experts. The protocols that had been implemented at this time, reflected State Department official Francis Colt De Wolf two decades later, would serve as a "guide for all international policing of the radio spectrum. ${ }^{\prime 4}$ De Wolf exaggerated: in Europe, the radio broadcasting spectrum had been allocated since 1925 by the International Broadcasting Union, a broadcaster-led organization that operated in tandem with the International Radiotelegraph Union.

Even so, the protocols devised in 1927 would open the way for the first postSecond World War international communications conference, which occurred in 1947. Like the 1927 conference, this conference-which was, in fact, a series of network-specific conferences that met simultaneously-also convened in the United States, this time in Atlantic City, New Jersey, rather than Washington, DC.

The Atlantic City conferences created the regulatory framework for a postwar technocratic corporatism in which the United States had firmly established itself as a dominant player on the world stage. In the interwar period, the technocratic

42 Harbord, "America's Position in Radio Communication," 470, 473.

43 Le Roy, "International Radiotelegraph Conference," 86-87.

44 Colt De Wolf, "Telecommunications in the New World," 1282. 
dream of a borderless world had stirred the imagination of certain corporate leaders and government administrators in United States and Europe. ${ }^{45}$ Following the Second World War, this dream, long an article of faith for US corporate network providers, would become a global norm. ${ }^{46}$

Among the defining features of this technocratic corporatism was its revival, albeit in a decidedly less journalistically centric guise, of Rogers's faith in the salutary potential of the unimpeded flow of information. "Statesmen must insist that intelligence may freely cross international boundaries," De Wolf explained, in surveying the results of the 1947 meeting: "Freedom of information must be a cornerstone of the new world, so that every man in every country will be free to choose what he wants to see and hear from what men in every other country offer to show and tell him." 47

To be sure, limits existed: member countries retained the right to block the transmission of any telegraphic dispatch, radio broadcast, or telephone call that violated their laws or threatened their national interest. Yet the presumption that the free flow of information had become a universal norm was widely shared among political and corporate leaders in the United States and its allies, and would find expression in the following year in the 1948 United Nations-sponsored International Declaration of Human Rights. ${ }^{48}$

45 The technocratic vision of a borderless world did not necessarily challenge the power and authority of sovereign governments. Yet it did accord more autonomy to corporations than the liberal internationalism of the interwar era. In thinking about the relationship of technology, corporations, and governments, I have found useful Edgerton, "The Contradictions of TechnoNationalism and Techo-Globalism." Edgerton provides a salutary caution for those recent historians who recycle the "techno-globalist propaganda" of twentieth-century network providers. "For many of technologies invoked as being somehow essentially internationalizing," Egerton observes, "were profoundly national in origin and use. Radio, which had a military origin, was intimately connected to national power. The development of the radio before the Great War was intimately tied to navies-indeed the Royal Navy was the largest single customer of the Marconi Company, which led the world in radio. During and after the Great War, radio and the military remained closely tied; the Radio Corporation of America, for example, was closely tied to the US state" (13).

46 The technocratic faith of US corporate leaders in a borderless world went back at least as the 1910s, when it helped inspire the completion by Bell of a transcontinental telephone link. John, Network Nation, 389-93.

47 De Wolf, "Telecommunications in the New World," 1290.

48 Codding, "Jamming and the Protection of Frequency Assignments," 385. To contend that the International Telecommunication Union promoted technocratic corporatism in 1947 is not to contend that this regulatory regime lacked a political agenda. Indeed, in certain ways post1947 international communications regulations institutionalized a "virtual telephone cartel." On this point, see Cowhey, "The International Telecommunications Regime." Too often, Cowhey 
The post-Second World War idealization of information flows is sometimes hailed as a logical outcome of Rogers's liberal internationalism. In fact, to the extent that international communications regulations in this period ceased to prioritize the circulation of information on current events, it had more in common with the technocratic corporatism Rogers despised than the liberal internationalism he had envisioned in his 1919 memorandum to President Wilson, and that he had tried unsuccessfully to institutionalize by lobbying in the following year for the establishment of the Universal Electrical Communications Union.

\subsection{Conclusion}

International communications regulation in the first half of the twentieth century underwent a shift from a liberal internationalism overseen by sovereign govemments to a technocratic corporatism coordinated by ostensibly neutral norms. Technocratic corporatism was designed by and for a cosmopolitan elite whose allegiance to a specific territory-whether a city, region, or nation-could not be taken for granted. ${ }^{49}$ In the years since 1947 , the regulation of intemational communications would increasingly become the prerogative less of national govemments than of multinational and, increasingly, transnational corporations. These corporations, in turn, have come to be run by a small yet influential cosmopolitan elite that champions a conception of an international political economy that has come to be known as neoliberalism.

Such a political economy presumed the emergence of a borderless world in which the circulation of information, people, and goods was regulated not by spatially bounded jurisdictions, which, by virtue of the fact that they were territorially delimited, were responsive, at least, in principle, to their inhabitants, but, rather, by a cosmopolitan elite beholden to no authority other than a global market for goods and services that they largely controlled.

Whether or not this twenty-first century variant on mid-twentieth-century technocratic corporatism can survive the myriad challenges that confront it, it is currently coming under increasing strain-buffeted by a resurgent nationalism resentful of cosmopolitan elites and dubious of open borders-reviving, perhaps,

observes, commentators on international communications have relied on the "cognitive frameworks" of participants to justify their rationale, while the "history of telephone systems are closer to myth than reality but nicely fit the political bargain underlying the regime" $(182,184)$. As a case in point, he emphasizes the "epistemic community" among telecommunications insiders that defended "national monopoly" (198).

49 Schot and Lagendijk, "Technocratic Internationalism in the Interwar Years." 
the possibility in a new and different modality of the liberal internationalism that Rogers had championed in Washington in 1920 and that would help to define the possibilities and the limitations of the International Telegraph Union as a global actor in the interwar era.

\section{References}

Aitken, Hugh. The Continuous Wave: Technology and American Radio, 1900-1932. Princeton: Princeton University Press, 1985.

Codding, George A., Jr. "Jamming and the Protection of Frequency Assignments." American Journal of International Law, vol. 49, n. 3 (1955): 384-88.

Cowhey, Peter F. "The International Telecommunications Regime: The Political Roots of

Regimes for High Technology." International Organization, vol. 44, n. 2 (1990): 169-99. Creel, George. How We Advertised America. New York: Harper \& Brothers, 1920.

De Wolf, Francis Colt. "Telecommunications in the New World." Yale Law Journal, vol. 55, n. 5 (1946): 1281-90.

Douglas, Susan J. Inventing American Broadcasting, 1899-1922. Baltimore: Johns Hopkins University Press, 1987.

Edgerton, David E. "The Contradictions of Techno-Nationalism and Techo-Globalism:

A Historical Perspective." New Global Studies, vol. 1, n. 1 (2007): 1-32.

Hapgood, David. Charles R. Crane: The Man Who Bet on People. Washington, DC: Institute of Current World Affairs, 2000.

Harbord, James G. "America's Position in Radio Communication." Foreign Affairs, vol. 4, n. 3 (1926): $465-74$.

John, Richard R. "The Public Image of the Universal Postal Union in the Anglophone World, 1874 -1949." In Exorbitant Expectations: International Organizations and the Media in the Nineteenth and the Twentieth Centuries, edited by Jonas Brendebach, Martin Herzer, and Heidi J.S. Tworek, 38-69. London: Routledge, 2018.

John, Richard R. Network Nation: Inventing American Telecommunications. Cambridge, MA: Belknap Press of Harvard University Press, 2010.

Le Roy, Howard S. "International Radiotelegraph Conference." American Bar Association Journal, vol. 14, n. 2 (1928): 86-90.

Mackay, Clarence H. International Cable Communication. Washington, DC: Government Printing Office, 1921.

Manela, Erez. The Wilsonian Moment: Self-Determination and the International Origins of Anticolonial Nationalism. New York: Oxford University Press, 2007.

McCune, Meghan Menard, and John Maxwell Hamilton, "'My object is to be of service to you': Carl Ackerman and the Wilson Administration during World War I." Intelligence and National Security, vol. 32, n. 6 (2017): 743-57.

Rogers, Walter S. "International Electrical Communications." Foreign Affairs, vol. 1, n. 2 (1922): $144-57$.

Rogers, Walter S. "Memorandum on Wire and Radio Communications." In Woodrow Wilson and World Settlement: Written from his Unpublished and Personal Material Vol. 3, edited by Ray Stannard Baker, 427-442. New York: Doubleday, Page \& Company, 1922. 
Schot, Johan, and Vincent Lagendijk. "Technocratic Internationalism in the Interwar Years: Building Europe on Motorways and Electricity Networks." Journal of Modern European History, vol. 6, n. 2 (2008): 196-217.

Schwoch, James. The American Radio Industries and its Latin American Activities, 1900-1930. Urbana: University of Illinois Press, 1990.

Schwoch, James. "The American Radio Industry and International Communications

Conferences, 1919 -1927." Historical Journal of Film, Radio and Television, vol. 7, n. 2 (1987): 289-309.

Tomlinson, John D. The International Control of Radiotelecommunications. Ann Arbor: J. W. Edwards, 1945.

Winseck, Dwayne R., and Robert M. Pike. Communications and Empire: Media, Markets, and Globalization, 1860-1930. Durham, NC: Duke University Press, 2007. 


\section{History of the International Telecommunication Union (ITU)}

Transnational techno-diplomacy from the telegraph to the Internet

Edited by

Gabriele Balbi and Andreas Fickers 
ISBN 978-3-11-066960-2

e-ISBN (PDF) 978-3-11066970-1

e-ISBN (EPUB) 978-3-11-066977-0

ISSN 2629-5059

Library of Congress Control Number: 2020932544

Bibliographic information published by the Deutsche Nationalbibliothek

The Deutsche Nationalbibliothek lists this publication in the Deutsche Nationalbibliografie; detailed bibliographic data are available on the Internet at http://dnb.dnb.de.

(1) 2020 Walter de Gruyter GmbH, Berlin/Boston

Cover image: Drawing of International Telecommunication Union (ITU) Plenipotentiary

Conference held in Geneva in 1959; Reproduced with the kind permission of ITU

Druck und Bindung: LSC Communications, United States

www.degruyter.com 


\section{Table of Contents}

Gabriele Balbi and Andreas Fickers

Introduction: The ITU as Actor, Arena, and Antenna of Techno-Diplomacy - 1

\section{Part I ITU as a Global Actor in the History of} Telecommunications

Marsha Siefert

1 The Russian Empire and the International Telegraph Union, 1856$1875-15$

Andrea Giuntini

2 ITU, Submarine Cables and African Colonies, 1850s-1900s - 37

Richard R. John

3 When Techno-Diplomacy Failed: Walter S. Rogers, the Universal Electrical Communications Union, and the Limitations of the International Telegraph Union as a Global Actor in the 1920s - 55

\section{Christiane Berth}

4 ITU, the Development Debate, and Technical Cooperation in the Global South, 1950-1992 — 77

Gianluigi Negro

5 The Rising Role of China in the Promotion of Multilateral Internet Governance, 1994-2014-107

Dwayne Winseck

6 Is the International Telecommunication Union Still Relevant in "the Internet Age?" Lessons From the $\mathbf{2 0 1 2}$ World Conference on International Telecommunications (WCIT) -135 


\section{Part II ITU as an Arena of Techno-Diplomatic Negotiations for Emerging Technologies}

\section{Simone Fari}

7 Telegraphic Diplomacy From the Origins to the Formative Years of the ITU, 1849-1875- 169

\section{Maria Rikitianskaia}

8 The International Radiotelegraph Union Over the Course of World War I, 1912-1927 — 191

Christian Henrich-Franke and Léonard Laborie

$9 \quad$ Technology Taking Over Diplomacy? The 'Comité Consultatif International (for) Fernschreiben' (CCIF) and Its Relationship to the ITU in the Early History of Telephone Standardization, 1923$1947-215$

Heidi Tworek

10 A Union of Nations or Administrations? Voting Rights, Representation, and Sovereignty at the International Telecommunication Union in the 1930s - 243

Anne-Katrin Weber, Roxane Gray, Marie Sandoz, with the collaboration of Adrian Stecher

11 ITU Exhibitions in Switzerland: Displaying the "Big Family of Telecommunications," 1960s-1970s — 265

Nina Wormbs and Lisa Ruth Rand

12 Techno-Diplomacy of the Planetary Periphery, 1960s - 1970s

Valérie Schafer

13 The ITU Facing the Emergence of the Internet, 1960s - Early 2000 s - 321

Index -345 